\title{
Chromosomal aberrations in ascetic fluid of metastatic gastric cancer patients: A clustering analysis
}

\author{
T. NAYEBBAGHER ${ }^{1,2,3}$, H. PASHAIEFAR ${ }^{1,2,3}$, M. YAGHMAIE ${ }^{1,2,3, *}$, K. ALIMOGHADDAM ${ }^{1,2,3}$, M. JALILI ${ }^{1,2,3}$, M. ESFANDBOD $^{4}$, M. SABERIAN $^{5}$, \\ H. BEHROOZI ${ }^{1,2,3}$, M. IZADIFARD ${ }^{1,2,3}$, A. GHAVAMZADEH ${ }^{1,2,3}$
}

${ }^{1}$ Hematology, Oncology and Stem Cell Transplantation Research Center, Tehran University of Medical Sciences, Tehran, Iran; ${ }^{2}$ Cell Therapy and Hematopoietic Stem Cell Transplantation Research Center, Tehran University of Medical Sciences, Tehran, Iran; ${ }^{3}$ Hematologic Malignancies Research Center, Tehran University of Medical Sciences, Tehran, Iran; ${ }^{4}$ Sina Hospital, Tehran University of Medical Sciences, Tehran, Iran; ${ }^{5}$ AJA University of Medical Sciences, Vali-Asr Hospital, Tehran, Iran

${ }^{*}$ Correspondence: m-yaghmaie@sina.tums.ac.ir

Received February 2, 2019 / Accepted June 1, 2019

\begin{abstract}
To date, no specific pattern of chromosomal abnormalities has been established in gastric cancer (GC). Cytogenetic analysis was performed using G-banding and fluorescence in situ hybridization (FISH) in 9 ascetic fluids from GC patients, and the clustering patterns of chromosomal abnormalities were studied. Twenty-six different types of chromosomal abnormalities were identified. In contrast to structural abnormalities, the gain or loss of chromosomes was infrequent. Moreover, five main clusters of chromosomal abnormalities were identified by clustering analysis. Extensive cytogenetic complexity, specific chromosomal abnormalities and karyotype heterogeneity are the main characterizations of GC. Some of the recurrent and novel chromosomal abnormalities with distinct clustering patterns identified in this study may play important roles for GC initiation and progression and could serve as promising diagnostic and prognostic markers in GC patients.
\end{abstract}

Key words: chromosomal abnormalities, ascetic fluids, clustering analysis, gastric cancer

Gastric cancer (GC), despite poor survival rates, is one of the most prevalent cancers around the world, accounting for a considerable amount of cancer-related morbidity and mortality [1]. Although environmental factors such as Helicobacter pylori infections, diet, and smoking play critical roles in the pathogenesis of GC, it is widely accepted that this type of tumor arises from complex genetic and environmental interactions contributing to the initiation and progression of the cancer $[2,3]$.

Like other types of solid tumors, cytogenetic studies to detect specific and recurrent chromosomal abnormalities in GCmaybehelpful in identifying causal genes that contribute to tumorigenesis [4]. Moreover, recurrent chromosomal abnormalities may provide important markers for determining the prognosis and clinical outcome of gastric cancer patients.

Recent studies have shown that chromosomal aberrations are linked to the histological type, survival, and further clinicopathological parameters of GC patients [5-7]. Several CGH studies in GC patients have indicated that there were both concordant and discordant correlations between specific chromosomal abnormalities and clinicopathological features of patients $[8,9]$.
Because of technical limitations, minimal information has become available regarding specific chromosomal alterations in GC patients. Although numerous chromosomal aberrations comprising simple and complex chromosomal changes have been reported, a specific pattern of chromosomal aberrations has yet to be identified for GC patients [10]. Conventional karyotyping of cancerous effusions of GC patients indicated karyotype complexity with frequent rearrangements of chromosomes 3,5 and 17, and the gain of chromosomes 7 and 13 [11]. Chromosomal analysis revealed that some GC patients have simple numerical chromosomal aberrations, like an isolated gain of chromosomes 8, 9, 19 and $\mathrm{X}$, or simple structural chromosomal aberrations like an isolated del (7q) and $\mathrm{i}(8 \mathrm{q})$. In other GC patients, complex karyotypes have been described $[12,13]$.

Through Giemsa-banding and fluorescence in situ hybridization (FISH), the chromosomes obtained from the cancerous ascetic fluids of 9 patients with GC were examined in this study. The results are analyzed herein together with the results of previously reported studies in order to identify recurrent or novel chromosomal abnormalities in GC. The clustering patterns of detected chromosomal abnormalities 
were also studied in an attempt to identify the association patterns of specific aberrations.

This study was undertaken to determine the potential value of the cytogenetic analysis of ascites fluids and to characterize recurrent chromosomal breakpoints and translocations specific to human GC to better understand the genetic make-up of gastric tumors. This study shows the feasibility and advantage of using FISH and karyotyping to find complex abnormalities in the body fluid of these patients. Results from this study along with those of former studies demonstrate that extensive cytogenetic complexity and karyotype heterogeneity are the main cytogenetic characterizations of metastatic gastric cancer. Moreover, a variety of cytogenetic alterations in different clustering patterns may possibly have a key role in GC pathogenesis and progression.

\section{Patients and methods}

Patients. A total of nine patients diagnosed with metastatic gastric cancer were included in this study. The general and clinicopathological characteristics of the patients are presented in Table 1. The pathological staging of the disease was based on the revised tumor-node-metastasis classification system [14]. The histological diagnoses were based on the criteria of the World Health Organization [15]. All patients received $60 \mathrm{mg} / \mathrm{m}^{2}$ of docetaxel, $50 \mathrm{mg} / \mathrm{m}^{2}$ of oxaliplatin, followed by $2500 \mathrm{mg} / \mathrm{m}^{2}$ daily of fluorouracil continuous infusions over $24 \mathrm{~h}$ for 5 days. The Ethics Committee of Tehran University of Medical Sciences (TUMS) approved this study, and informed consent was obtained from all participants prior to sampling.

Direct chromosome preparation. Approximately 20 $\mathrm{ml}$ of ascetic fluid from the patients were collected into tubes containing transfer media (complete RPMI1640 media supplemented with $10 \%$ fetal bovine serum (FBS), $1 \%$ penicillin/streptomycin). The collected specimens were centrifuged at $3000 \mathrm{rpm}$ for $15 \mathrm{~min}$. The supernatant was then discarded. Next, the cells were diluted 1:6 in a culture medium (RPMI1640 supplemented with a 20\% FBS). Colcemid was added to the $25 \mathrm{~cm}^{2}$ culture flasks with a final concentration of $0.05 \mu \mathrm{g} / \mathrm{ml}$. The flasks were incubated at $37^{\circ} \mathrm{C}$ for $20-30$ min followed by centrifugation at $3000 \mathrm{rpm}$ for $15 \mathrm{~min}$. The pelleted cells were resuspended in $10 \mathrm{ml}$ of pre-warmed 0.075 $\mathrm{M} \mathrm{KCl}$ and allowed to swell for 10-12 min. The cells were spun down, the supernatant was discarded, and the cells were fixed three times in chilled fixative (3:1, methanol: acetic acid). After $10 \mathrm{~min}$, the cells were again centrifuged and resuspended and used for slide preparation by conventional air-drying methods. The chromosomes were G-banded using pancreatin and analyzed based on the International System for Human Cytogenomic Nomenclature (ISCN) 2016 [16].

Cell cultures for chromosome preparations. The ascites fluid was cultured $\left(1 \times 10^{6}\right.$ cells $\left./ \mathrm{ml}\right)$ in a $5 \mathrm{ml}$ RPMI 1640 medium supplemented with $20 \% \mathrm{FBS}, 1 \%$ penicillin/streptomycin, and $1 \% \mathrm{~L}$-glutamine. The long-term culture was conducted at $37^{\circ} \mathrm{C}$ for $48-96 \mathrm{~h}$ in a humidified atmosphere of $5 \% \mathrm{CO}_{2}$. Thereafter, $1 \mathrm{ml}$ of trypsin-EDTA was added, and the culture was incubated for $3-5 \mathrm{~min}$ at $37^{\circ} \mathrm{C}$. Next, the cells were exposed to colcemid $(0.05 \mu \mathrm{g} / \mathrm{ml})$ for $20 \mathrm{~min}$, followed by processing in a pre-warmed $0.075 \mathrm{M} \mathrm{KCl}$ for $30 \mathrm{~min}$, which subsequently underwent fixation. Slides were stained with a Giemsa solution pretreated with pancreatin. Accordingly, karyotyping was performed on slides with a range of 10 to 15 metaphases.

Fluorescence in situ hybridization (FISH). FISH was carried out to confirm chromosomal abnormalities detected by G-banding. The FISH probes used for confirmation are listed in Table 3. The G-banded slides were de-stained by methanol and then immersed into a $2 \times$ (SSC) saline sodium citrate buffer for $2 \mathrm{~min}$ at room temperature, followed by dehydration in a graded ethanol series $(70 \%, 85 \%, 90 \%$, and $100 \%$, each for 1 to $2 \mathrm{~min}$ ). Then, $1.5 \mu \mathrm{l}$ of the probe mixture was spotted onto the marked metaphases and sealed with a cover slip thru a rubber glue solution. Denaturation was performed at $76^{\circ} \mathrm{C}$ for $5 \mathrm{~min}$. For $13-15 \mathrm{~h}$, the slides were hybridized at $37^{\circ} \mathrm{C}$. Afterwards, the slides were washed in $0.4 \mathrm{x} \mathrm{SSC}$ at $75^{\circ} \mathrm{C}$ for $2 \mathrm{~min}$ and were then immersed in $2 \times$ SSC, $0.1 \% \mathrm{NP} 40(\mathrm{pH}=7.0)$ solution at room temperature for one minute. After using DAPI (Cytocell, UK/Abott Molecular, USA) on each slide for staining the nuclei, FISH signals were evaluated on a minimum of 100 interphase nuclei using a fluorescence microscope (Olympus, BX51, Japan).

Table 1. Clinicopathological characteristics of gastric cancer patients with a diagnosis of adenocarcinoma.

\begin{tabular}{lllccccccl}
\hline $\begin{array}{l}\text { Case } \\
\text { No. }\end{array}$ & Sex & Histologic Grades & $\begin{array}{c}\text { Tumor } \\
\text { Location }\end{array}$ & $\begin{array}{c}\text { Greatest tumor } \\
\text { dimension }\end{array}$ & $\begin{array}{c}\text { Vascular } \\
\text { invasion }\end{array}$ & $\begin{array}{c}\text { Lymphatic } \\
\text { invasion }\end{array}$ & TNM & Stage & Survival status \\
\hline 1 & Male & Poorly differentiated & Cardia & $30 \mathrm{~mm}$ & + & + & T2N1M1 & IV & Death (14 months after diagnosis) \\
2 & Male & Well differentiated & Antropyloric & - & - & - & T3N0M0 & III & Death (10 months after diagnosis) \\
3 & Male & Well differentiated & Cardia & $130 \mathrm{~mm}$ & + & - & T3N1M0 & II & Death (8 months after diagnosis) \\
4 & Male & Poorly differentiated & Cardia & $65 \mathrm{~mm}$ & + & + & T3N1M1 & IV & Alive \\
5 & Male & Poorly differentiated & Fundus & $8 \mathrm{~mm}$ & + & - & T3N3M0 & II & Death (8 months after diagnosis) \\
6 & Male & Poorly differentiated & Fundus & $7 \mathrm{~mm}$ & + & - & T3N1M0 & IV & Death (3 months after diagnosis) \\
7 & Male & Poorly differentiated & Cardia & $45 \mathrm{~mm}$ & + & + & T4N2M1 & IV & Alive \\
8 & Male & Poorly differentiated & - & - & + & + & T3N1M1 & III & Alive \\
9 & Male & Poorly differentiated & Cardia & $50 \mathrm{~mm}$ & - & - & T2N0M0 & III & Death (8 months after diagnosis $)$ \\
\hline
\end{tabular}




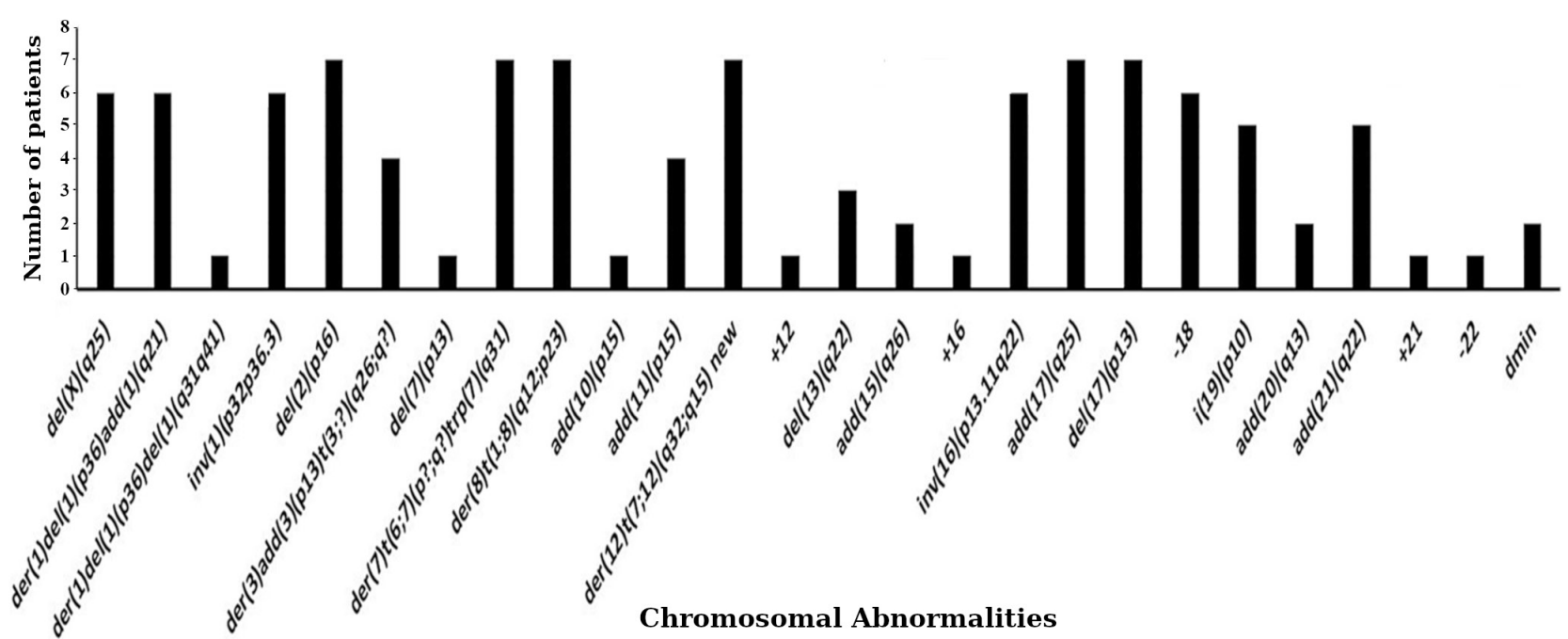

Figure 1. The distribution of chromosomal abnormalities in 9 metastatic gastric cancer patients. The y-axis shows the number of patients harboring relevant chromosomal abnormalities.

Table 2. Karyotypes obtained from 9 patients with gastric cancer.

\begin{tabular}{|c|c|c|}
\hline $\begin{array}{l}\text { Case } \\
\text { No. }\end{array}$ & Modal Number & Karyotypes \\
\hline 1 & Hypotriploid & $\begin{array}{l}\text { 67 68,XY,del(X)(25)[15], inv(1)(p32p36.3)×2[14], der(1)del(1)(p36)add(1)(q21)[13],del(2)(p16)[15], der(3)add(3)(p13) } \\
\mathrm{t}(3 ; ?)(\mathrm{q} 26 ; ?)[13], \operatorname{der}(7) \mathrm{t}(6 ; 7)(\mathrm{p} ? ; \mathrm{q} ?) \operatorname{trp}(7)(\mathrm{q} 31)[15], \operatorname{der}(8) \mathrm{t}(1 ; 8)(\mathrm{q} 12 ; \mathrm{p} 23)[15], \operatorname{add}(11)(\mathrm{p} 15)[13], \operatorname{der}(12) \mathrm{t}(7 ; 12)(\mathrm{q} 32 ; \mathrm{q} 15) \\
{[15], \operatorname{inv}(16)(\mathrm{p} 13 \mathrm{q} 22)[13], \operatorname{del}(17)(\mathrm{p} 13)[15], \operatorname{add}(17)(\mathrm{q} 25)[14],-18[13], \mathrm{i}(19)(\mathrm{p} 10)[13][\mathrm{cp} 15]}\end{array}$ \\
\hline 2 & Hypertriploid & $\begin{array}{l}\text { 70,XY, del(X)(q25)[6] inv(1)(p32p36.3)×2[13],der(1)del(1)(p36)add(1)(q21)[15], del(2)(p16)[15],der(7)t }(6 ; 7)(\mathrm{p} ? ; \mathrm{q} ?) \operatorname{trp}(7) \\
(\mathrm{q} 31) \times 2[15], \operatorname{der}(8) \mathrm{t}(1 ; 8)(\mathrm{q} 12, \mathrm{p} 23)[15], \operatorname{add}(11)(\mathrm{p} 15)[9], \operatorname{der}(12) \mathrm{t}(7 ; 12)(\mathrm{q} 32 ; \mathrm{q} 15)[11], \operatorname{del}(13)(\mathrm{q} 22)[7], \operatorname{inv}(16)(\mathrm{p} 13.11 \mathrm{q} 22) \\
{[9], \operatorname{del}(17)(\mathrm{p} 13)[10],+\operatorname{add}(17)(\mathrm{q} 25)[15], \mathrm{i}(19)(\mathrm{p} 10)[10], \operatorname{add}(21)(\mathrm{q} 22)[6],+\operatorname{dmin}[8][\mathrm{cp} 15]}\end{array}$ \\
\hline 3 & Hypotriploid & 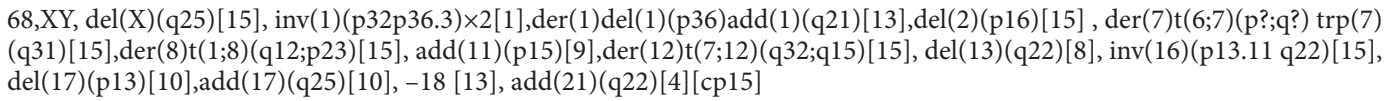 \\
\hline 4 & Hypotriploid & $\begin{array}{l}\text { 68,XY inv(1)(p32p36.3)×2[10],der(1)del(1)(p36)add(1)(q21)[8], del(2)(p16)[15],der(3)add(3)(p13) t(3;?)(q26;?)[8], der (7) } \\
\mathrm{t}(6 ; 7)(\mathrm{p} ? ; \mathrm{q} ?) \operatorname{trp}(7)(\mathrm{q} 31)[15], \operatorname{der}(8) \mathrm{t}(1 ; 8)(\mathrm{q} 12 ; \mathrm{p} 23)[12], \operatorname{der}(12) \mathrm{t}(7 ; 12)(\mathrm{q} 32 ; \mathrm{q} 15)[10], \operatorname{inv}(16)(\mathrm{p} 13.11 \mathrm{q} 22)[9], \operatorname{del}(17)(\mathrm{p} 13) \\
\text { [15],add(17)(q25)[15], -18[10],i (19)(p10)[6],add(20)(q13)[7][cp15] }\end{array}$ \\
\hline 5 & High Hyperdiploid & $\begin{array}{l}53, \mathrm{XY},+\operatorname{del}(\mathrm{X})(\mathrm{q} 25)[10],+\operatorname{del}(2)(\mathrm{p} 16)[15],+\operatorname{der}(7) \mathrm{t}(6 ; 7)(\mathrm{p} ? ; \mathrm{q} ?) \operatorname{trp}(7)(\mathrm{q} 31)[13],+\operatorname{der}(8) \mathrm{t}(1 ; 8)(\mathrm{q} 12 ; \mathrm{p} 23)[12],+\operatorname{der}(12) \mathrm{t}(7 ; 12) \\
(\mathrm{q} 32 ; \mathrm{q} 15)[9],+\operatorname{del}(17)(\mathrm{p} 13)[8],+\operatorname{add}(17)(\mathrm{q} 25)[9],-18[5],+\operatorname{add}(21)(\mathrm{q} 22)[6][\mathrm{cp} 15]\end{array}$ \\
\hline 6 & Hyperdiploid & $47, \mathrm{XY},+21[15]$ \\
\hline 7 & Hyperdiploid & $47, \mathrm{XY},+12[15]$ \\
\hline 8 & Hypotriploid & $\begin{array}{l}\text { 68,XY,del }(\mathrm{X})(\mathrm{q} 25)[8], \operatorname{inv}(1)(\mathrm{p} 32 \mathrm{p} 36.3) \times 2[13\}, \operatorname{der}(1) \operatorname{del}(1)(\mathrm{p} 36) \operatorname{add}(1)(\mathrm{q} 21)\{8], \operatorname{del}(2)(\mathrm{p} 16)[15], \operatorname{der}(3) \operatorname{add}(3)(\mathrm{p} 13) \mathrm{t}(3 ; ?) \\
(\mathrm{q} 26 ; ?)[7], \operatorname{der}(7) \mathrm{t}(6 ; 7)(\mathrm{p} ? \mathrm{q} ?) \operatorname{trp}(7)(\mathrm{q} 31)[7], \operatorname{der}(8) \mathrm{t}(1 ; 8)(\mathrm{q} 12 ; \mathrm{p} 23)[5], \operatorname{add}(10)(\mathrm{p} 15)[5], \operatorname{der}(12) \mathrm{t}(7 ; 12)(\mathrm{q} 32 ; \mathrm{q} 15)[6], \operatorname{del}(13) \\
(\mathrm{q} 22)[5], \operatorname{add}(15)(\mathrm{q} 26)[4], \operatorname{inv}(16)(\mathrm{p} 13.11 \mathrm{q} 22)[10], \operatorname{del}(17)(\mathrm{p} 13)[7], \operatorname{add}(17)(\mathrm{q} 25)[7],-18[11], \mathrm{i}(19)(\mathrm{p} 10)[9], \operatorname{add}(21)(\mathrm{q} 22) \\
{[10][\mathrm{cp} 15]}\end{array}$ \\
\hline 9 & Hypertriploid & 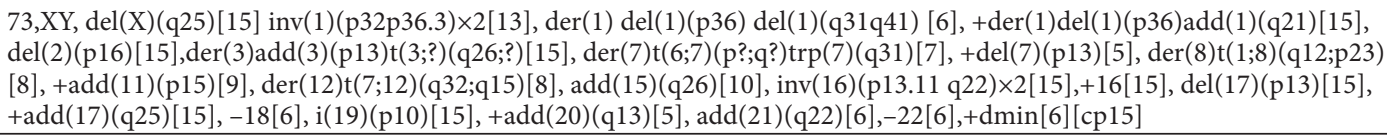 \\
\hline
\end{tabular}

Hierarchical clustering. A cluster analysis was performed to assess the association of chromosomal aberrations based on the frequency and type of chromosomal abnormalities within different patients. Each abnormality was scored as being present or absent within the karyotype of patients. Hierarchical clustering was achieved using the gplots package with $\mathrm{R}$ statistics software. The distance matrices were calculated using the Euclidean distance. Ward's method was used for hierarchical cluster analyses.

\section{Results}

Cytogenetic aberrations in metastatic gastric cancer. The modal chromosome number was hyperdiploid in two patients, high hyperdiploid in one patient, hypertriploid in two patients, and hypotriploid in four patients. Among the patients in this study, several recurrent structural chromosomal abnormalities were detected (Figure 1 and Table 2). In contrast to the structural abnormalities, the gain or loss of 

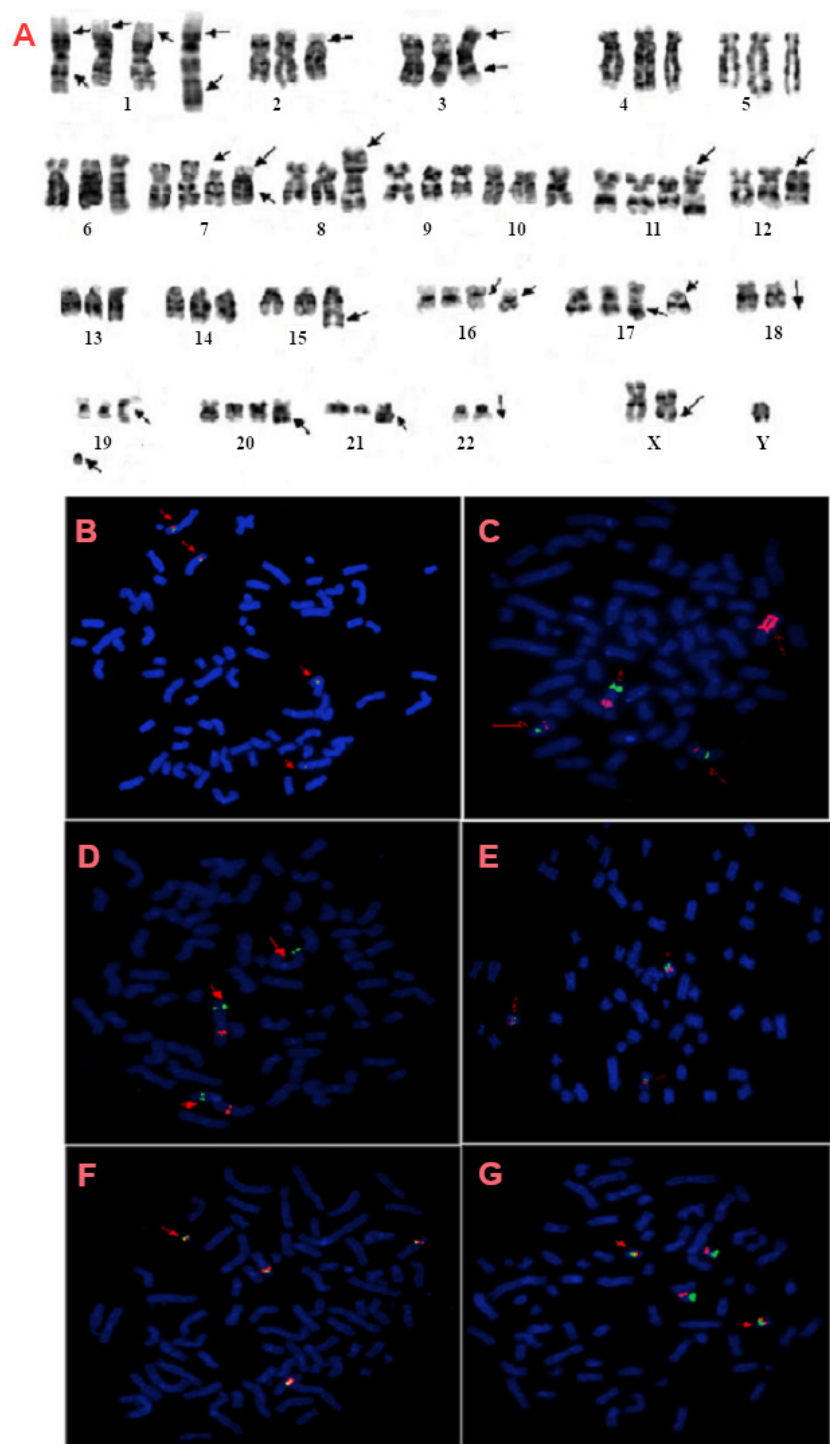

Figure 2. GTG-banded metaphase spread, karyotype and FISH obtained from case No. 9: A) An abnormal hypertriploid complex karyotype complement with the following chromosomal abnormalities: $73, \mathrm{XY}$ $\operatorname{del}(\mathrm{X})(\mathrm{q} 25)[15] \quad \operatorname{inv}(1)(\mathrm{p} 32 \mathrm{p} 36.3) \times 2[13], \quad \operatorname{der}(1) \quad \operatorname{del}(1)(\mathrm{p} 36) \quad \operatorname{del}(1)$ (q31q41) [6],+der(1)del(1)(p36) add(1)(q21) [15], del(2)(p16)[15],der(3) $\operatorname{add}(3)(\mathrm{p} 13) \mathbf{t}(3 ;$ ?) $(\mathrm{q} 26 ; ?)[15], \quad \operatorname{der}(7) \mathbf{t}(6 ; 7)(\mathrm{p}$ ?; q?)trp(7)(q31)[7],+del(7) (p13) [5], $\quad \operatorname{der}(8) \mathbf{t}(1 ; 8)(\mathrm{q} 12 ; \mathrm{p} 23)[8], \quad+\operatorname{add}(11)(\mathrm{p} 15)[9], \quad \operatorname{der}(12) \mathbf{t}(7 ; 12)$ $(\mathrm{q} 32 ; \mathrm{q} 15)[8], \quad \operatorname{add}(15)(\mathrm{q} 26)[10], \quad \operatorname{inv}(16)(\mathrm{p} 13.11 \quad \mathrm{q} 22) \times 2[15],+16[15]$, $\operatorname{del}(17)(\mathrm{p} 13)[15],+\operatorname{add}(17)(\mathrm{q} 25)[15],-18[6], \mathrm{i}(19)(\mathrm{p} 10)[15],+\operatorname{add}(20)$ (q13) [5], add(21) (q22)[6],-22[6], + dmin[6][cp15]. Arrows indicate abnormal chromosomes. B) FISH result by the Cytocell IGK break apart probe consisting of yellow-labeled IGK (2p11.2). C) FISH result by the Cytocell C-MET amplification probe consisting of red-labeled C-MET (7q31.2) and green-labeled D7Z1, 7p11.1-q11.1. D) FISH result by the Kreatech 1q21/ SRD(1p36) probe consisting of red-labeled SRD (1p36) and green-labeled 1q21. E) FISH result by the Cytocell MDM2 amplification probe consisting of red-labeled MDM2 (12q15) and green-labeled D12Z1, 12p11.1-q11.1. F) FISH result by the Cytocell C-MYC break apart probe consisting of yellow-labeled C-MYC (8q24). G) FISH result by the Kreatech CBFB $t(16 ; 16)$; inv(16) break apart probe consisting of red-labeled CBFB (16q22) and green-labeled MYHII (16p13.11) probe. A break signal is defined when the red/green signals apart from each other. Arrowheads of their respective colors in representative metaphase indicate hybridization signals. a whole chromosome was infrequently observed. Except for the loss of chromosome 18 that was frequent and detected in 6 patients, the loss of chromosome 22 and the gain of chromosomes 12,16 , and 21 each were detected in only one patient. The gain of chromosomes 12 and 21 was detected as the sole chromosomal abnormality in two cases (cases 6 and 7).

The most frequent structural chromosomal rearrangements were: $\operatorname{del}(17)(\mathrm{p} 13), \operatorname{der}(7) \mathrm{t}(6 ; 7)(\mathrm{p}$ ?; $\mathrm{q}) \operatorname{trp}(7)(\mathrm{q} 31)$, $\operatorname{del}(2)(\mathrm{p} 16)$, $\operatorname{add}(17)(\mathrm{q} 25)$ and $\operatorname{der}(8) \mathrm{t}(1 ; 8)(\mathrm{q} 12 ; \mathrm{p} 23)$, and $\operatorname{der}(12) \mathrm{t}(7 ; 12)(\mathrm{q} 32 ; \mathrm{q} 15)$ in 7 cases; followed by $\operatorname{der}(1) \operatorname{del}(1)$ (p36)add(1)(q21), inv(16)(p13.11 q22), inv(1)(p32p36.3), and $\operatorname{del}(\mathrm{X})(\mathrm{q} 25)$ in 6 cases, $\mathrm{i}(19)(\mathrm{p} 10)$ and $\operatorname{add}(21)(\mathrm{q} 22)$ in 5 cases, $\operatorname{der}(3) \operatorname{add}(3)(\mathrm{p} 13) \mathrm{t}(3 ;$ ?) $(\mathrm{q} 26 ;$ ? $)$ and $\operatorname{add}(11)(\mathrm{p} 15)$ in four cases, $\operatorname{del}(13)(\mathrm{q} 22)$ in 3 cases, $\operatorname{add}(20)$ (q13) and $\operatorname{add}(15)$ (q26) in 2 cases as well as $\operatorname{del}(7)(\mathrm{p} 13)$ and $\operatorname{der}(1) \operatorname{del}(1)(\mathrm{p} 36)$ $\operatorname{del}(1)(\mathrm{q} 31 \mathrm{q} 41)$ in one case (Figure 1$)$.

FISH results. FISH was performed using commercially available probes to confirm the presence or absence of particular cytogenetic aberrations as well as to identify the occurrence of translocation breakpoints (Figure 2). The results of the FISH signals for each chromosomal abnormality along with their associated chromosomal abnormalities are summarized in Table 3.

The clustering of chromosome aberrations. The clustering of cytogenetic abnormalities for all analyzed metaphases from the GC patients revealed five main clusters (Figure 3). The first cluster was characterized by frequently presented chromosomal abnormalities including: del(17) (p13), $\operatorname{add}(17)(\mathrm{q} 25), \operatorname{der}(12) \mathrm{t}(7 ; 12)(\mathrm{q} 32 ; \mathrm{q} 15), \operatorname{der}(8) \mathrm{t}(1 ; 8)$ $(\mathrm{q} 12 ; \mathrm{p} 23), \operatorname{der}(7) \mathrm{t}(6 ; 7)(\mathrm{p}$; q $) \operatorname{trp}(7)(\mathrm{q} 31), \operatorname{del}(2)(\mathrm{p} 16)$, and loss of chromosome 18 . The second cluster was identified by: $\operatorname{der}(1) \operatorname{del}(1)(\mathrm{p} 36) \operatorname{add}(1)(\mathrm{q} 21), \quad \operatorname{inv}(16)(\mathrm{p} 13.11 \mathrm{q} 22), \quad \operatorname{inv}(1)$ (p32p36.3), i(19)(p10), der(3) add(3)(p13)t(3;?)(q26;q?), the third cluster by: $\operatorname{del}(\mathrm{X})(\mathrm{q} 25)$ and $\operatorname{add}(21)(\mathrm{q} 22)$, add(11)(p15) and $\operatorname{del}(13)(\mathrm{q} 22)$, the fourth cluster by less frequent abnormalities including: gain of chromosome 16, loss of chromosome 22, $\operatorname{del}(7)(\mathrm{p} 13), \quad \operatorname{der}(1) \operatorname{del}(1)(\mathrm{p} 36) \operatorname{del}(1)(\mathrm{q} 31 \mathrm{q} 41)$, and $\operatorname{add}(20)(q 13)$, and the fifth one by rare abnormalities including: $\operatorname{add}(15)(\mathrm{q} 26)$, add(10)(p15), and gain of chromosomes 12 and 21 .

\section{Discussion}

In this study, chromosomal abnormalities and their clustering patterns in the cancerous ascetic fluids obtained from GC patients were analyzed. Structural aberrations of chromosome 17 as $\operatorname{del}(17)(\mathrm{p} 13) /$ loss of TP53 (in 7 cases) and $\operatorname{add}(17)(q 25)$ (in 7 cases) were the most frequent structural rearrangements in the cohort of patients in this study. In the case of GC, structural and numerical (often loss) abnormalities of chromosome 17 have been previously reported [13, 17, 18]. Formerly, Kobayashi et al. determined 17p13/TP53 alterations in GC patients using FISH analysis and reported TP53 deletion in 39\% of tumors [19]; however, the frequency 
Table 3. The results of the FISH signals and their associated chromosomal abnormalities.

\begin{tabular}{|c|c|c|}
\hline Chromosome aberration & FISH probe & $\begin{array}{l}\text { Result } \\
\text { (FISH signal) }\end{array}$ \\
\hline $\operatorname{inv}(1)(\mathrm{p} 32 \mathrm{p} 36.3) \times 2, \operatorname{der}(1) \operatorname{del}(1)(\mathrm{p} 36) \operatorname{del}(1)(\mathrm{q} 31 \mathrm{q} 41), \operatorname{der}(1) \operatorname{del}(1)(\mathrm{p} 36) \operatorname{add}(1)(\mathrm{q} 21)$ & $\operatorname{SRD}(1 \mathrm{p} 36 \mathrm{R} / 1 \mathrm{q} 12 \mathrm{G})$ & 2R3G \\
\hline $\operatorname{del}(2)(\mathrm{p} 16)$ & IGK Break apart(2p11.2 Y) & $4 \mathrm{Y}$ \\
\hline $\operatorname{add}(3)(\mathrm{p} 13) ? \mathrm{t}(3 ; ?)(\mathrm{q} 26 ; ?)$ & PPARG (3p25Y) & $3 \mathrm{Y}$ \\
\hline $\operatorname{der}(7) t(6 ; 7)(p ? ; q ?) \operatorname{trp}(7)(q 31)$ & MET amp (7q31R/CEP7G) & 7R $3 G$ \\
\hline $\operatorname{der}(8) t(1 ; 8)(q 12 ; p 23)$ & $\operatorname{SRD}(1 \mathrm{p} 36 \mathrm{R} / 1 \mathrm{q} 12 \mathrm{G})$ & $2 \mathrm{R} 3 \mathrm{G}$ \\
\hline $\operatorname{der}(12) t(7 ; 12)(q 32 ; q 15)$ & MDM2 Amplification(12q15R/CEP12G) & $3 R 3 G$ \\
\hline $\operatorname{inv}(16)(\mathrm{p} 13.11 \mathrm{q} 22)$ & CBFB/MYHII Dual fusion(16q22R/16p13G) & 2R2G2Y \\
\hline$+\operatorname{add}(17)(\mathrm{q} 25)$ & HER2 amplification(17q12R/CEP17G) & $4 \mathrm{R} 4 \mathrm{G}$ \\
\hline $\operatorname{del}(17)(\mathrm{p} 13)$ & P53 deletion(17p13R/CEP17G) & $2 \mathrm{R} 3 \mathrm{G}$ \\
\hline-18 & BCL2 Break apart(18q21 Y) & $2 \mathrm{Y}$ \\
\hline $\mathrm{i}(19)(\mathrm{p} 10)$ & E2A break apart(19p13.3 Y) & $4 \mathrm{Y}$ \\
\hline $\operatorname{add}(20)(q 13)$ & Satellite Enumeration probe $20(\mathrm{R})$ & $3 R$ \\
\hline$+\operatorname{add}(21)(q 22)$ & Satellite Enumeration probe $21(\mathrm{R})$ & $3 R$ \\
\hline $\operatorname{del}(\mathrm{X})(\mathrm{q} 25)$ & $\mathrm{X} / \mathrm{Y}(\mathrm{DXZ1R} / \mathrm{DYZ1} \mathrm{G})$ & $3 R$ \\
\hline
\end{tabular}

R: Red, Y: Yellow, G: Green

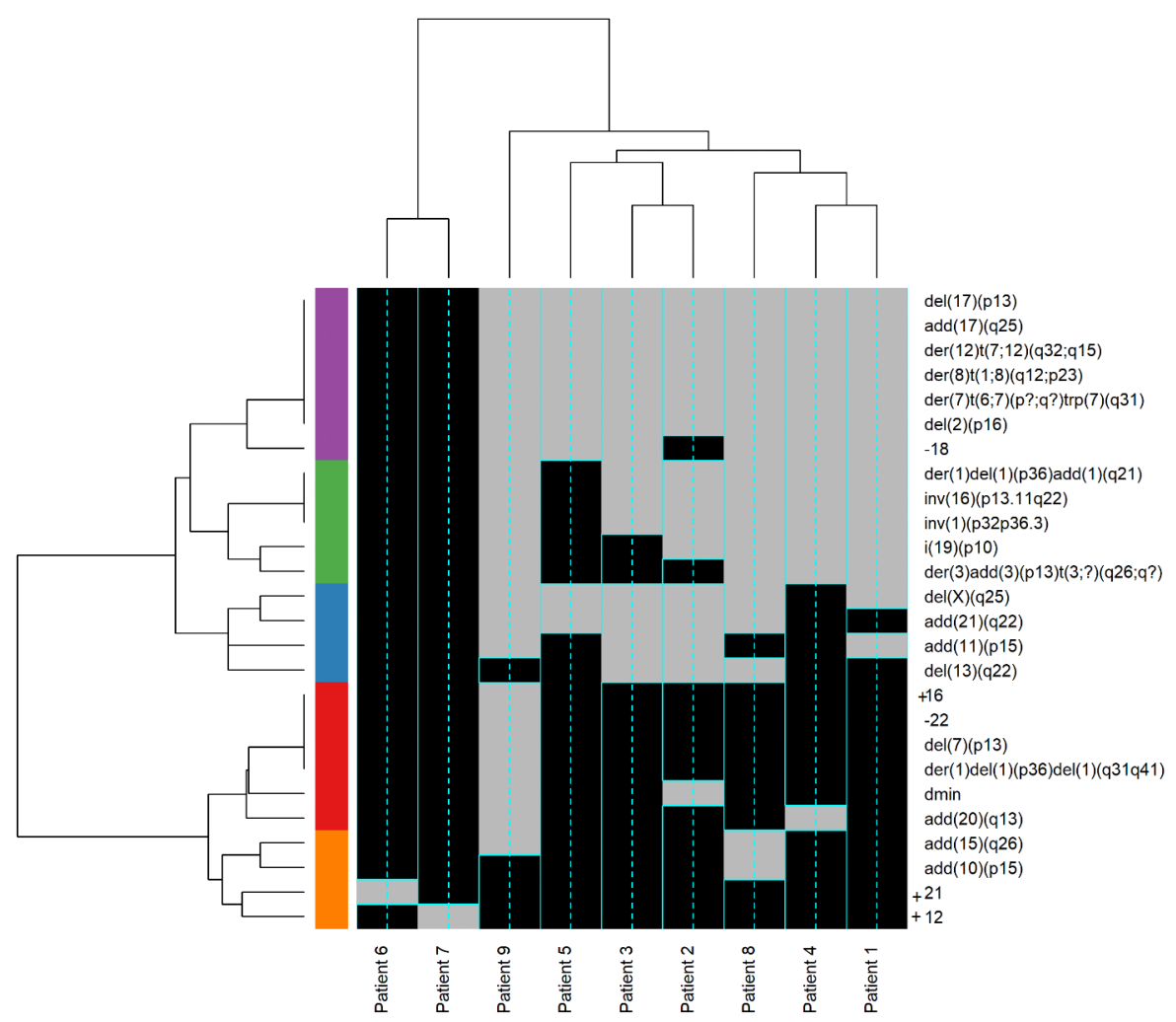

Figure 3. Hierarchical clustering based on the presence or the absence of chromosomal abnormalities detected in the gastric cancer patients. Each column represents a patient and each row denotes a chromosomal abnormality. Grey indicates the presence of each abnormality, and black indicates their absence.

of TP53 mutations varies greatly between different studies [20]. The TP53 deletion was detected in 7 out of 9 metastatic GC patients in the current study, suggesting its contributing role to the progression of GC.The results from cluster analysis revealed that chromosome 17 aberrations tend to be associ- ated with $\operatorname{del}(2)(\mathrm{p} 16)$ and $\operatorname{trp}(7)(\mathrm{q} 31)$, suggesting the possibility of a synergism between these aberrations to accelerate gastric tumorigenesis. The TP53 tumor suppressor gene, c-MET proto-oncogene, and the MSH6 DNA mismatch repair gene were located in $17 \mathrm{p} 13,7 \mathrm{q} 31$, and $2 \mathrm{p} 16$, respectively. A 
study by Young et al. previously demonstrated that the TP53 tumor suppressor and MSH6 DNA mismatch repair gene act together in accelerating genomic instability and tumorigenesis in mice models [21]. These results suggest that the loss of genes involved in the maintenance of genomic stability, such as TP53 and MSH6, may lead to the progression of GC.

The other most common structural abnormality detected in patients in the current study was amplification of $7 \mathrm{q} 31$, which contains the $c-M E T$ gene. Results from $\mathrm{CGH}$ array studies have shown that $7 \mathrm{q}$ copy-number alterations are one of the most frequent types of chromosomal abnormalities, which preferentially occur in advanced GC $[22,23]$. In this study, gains of $7 \mathrm{q}$ were found in 7 of the cases. This data confirms that $c-M E T$ amplification plays an important role in the progression of GC.

In addition, several non-reciprocal translocations were detected in the patients in the current study. Chromosomal bands repeatedly involved in non-reciprocal translocations comprised 1p36, 1q21, 3p13, 11p15, 15q26, 17q25, 20q13 and $21 \mathrm{q} 22$. The breakpoints detected in 3p13, 11p15, 15q26, 17q25, $20 q 13$ and 21q22 were previously reported in GC cell lines and GC patients using SKY analysis by Yamashita et al. [24].

The majority of structural chromosomal changes detected so far in GC patients are unbalanced; however, Panani et al. [18] previously described balanced translocations in 5 of their 15 primary GC cases, which involved several chromosomes including $\mathrm{t}(1 ; 7), \mathrm{t}(7 ; 14), \mathrm{t}(6 ; 17)$ and $\mathrm{t}(5 ; 14)$. In the current study, two balanced chromosomal aberrations were detected in our patients as inv(16)(p13.11 q22) and inv(1)(p32p36.3) and confirmed these aberrations by FISH method.

The $\operatorname{inv}(16)(\mathrm{p} 13.11 ; \mathrm{q} 22)$ is one of the most common chromosomal aberrations detected in acute myeloblastic leukemia (AML). This rearrangement disrupts the myosin heavy chain (MYH11) gene at the short arm of chromosome $16(16 \mathrm{p} 13.11)$ and the core binding factor $\beta(C B F B)$ gene at the long arm of this chromosome (16q22) [25]. Li et al. previously reported that the binding of the $C B F B$ to the transcription factor RUNX3 is required for gastrointestinal development, proliferation and differentiation [26]. Furthermore, a previous study showed that $C B F B$ was downregulated in gastric cancer, suggesting that $\mathrm{CBFB}$ may play an important role in the development of GC [27]. However, further investigations are essential to provide the possible relation between $\operatorname{inv}(16)(\mathrm{p} 13.11 ; \mathrm{q} 22)$ and tumorigenesis as well as the clinicopathological features of GC patients.

Moreover, partial deletions of chromosome 2, X, 13, and 7 as $\operatorname{del}(2)(\mathrm{p} 16), \operatorname{del}(\mathrm{X})(\mathrm{q} 25), \operatorname{del}(13)(\mathrm{q} 22)$, and $\operatorname{del}(7)(\mathrm{p} 13)$ were detected in $7,6,3$, and one of the cases, respectively.

Chromosome 13 alterations are very frequent in GC. A loss of heterozygosity at loci $13 \mathrm{q}$ is found in $59 \%$ of human stomach cancers [28]. The current most likely candidate gene at $13 \mathrm{q} 22$ is the EDNRB. Hypermethylation and low expression of the $E D N R B$ gene were previously reported in GC patients [29]. These results suggest that the loss of $13 \mathrm{q} 22$ may lead to the deletion of the EDNRB gene, thus, playing an important role in GC pathogenesis and progression. In contrast to the structural chromosomal aberrations, the gain and loss of a whole chromosome were infrequently observed except for the loss of chromosome 18 revealed in 6 patients.

A previous study showed that loss of chromosome $18 \mathrm{q}$ was associated with tumor progression in patients with primary gastric cancer [30]. Several well-known tumor suppressor genes such as DCC (Deleted in Colorectal Carcinoma), SMAD2 (SMAD Family Member 2), and SMAD4 (SMAD Family Member 4) are also located on chromosome 18, and their loss might play an important role in GC initiation and progression.

Previous gastric cancer studies have revealed a number of numerical chromosomal changes. The most frequent numerical aberrations previously reported in GC are copy number alterations of chromosomes $1,4,5,6,7,8,9,17,20, \mathrm{X}$ and $\mathrm{Y}[13$, 31]. Moreover, CGH analysis on GC cell lines have demonstrated that chromosomal gains are frequent in these cells [32].

There are conflicting results about the role of numerical chromosomal aberrations in GC patients. While some studies found no association between the numerical chromosomal aberrations and clinicopathological characteristics of GC patients $[33,34]$, other studies indicated an association between these two parameters [31,35]. Moreover, clustering analysis showed that a set of chromosomal abnormalities were similar in all metastatic GC patients with consistent complex cytogenetic abnormalities. These findings suggest that these chromosomal abnormalities may be an early event in GC progression and, through further studies in large cohorts of patients, they may be considered as diagnostic and prognostic markers for GC patients.

In conclusion, the present study demonstrated several chromosomal abnormalities with specific clustering patterns in ascites fluid of metastatic GC as a non-invasive source for karyotyping. Very little is known about the genetics of gastric tumors; thus, these findings may help us achieve a deep understanding of the genetic make-up of these patients and validate the chromosomal copy number changes in larger studies to find reliable diagnostic or prognostic markers. In addition, further studies of the GC genomic profiles and its correlation with clinicopathological features, may introduce chromosomal copy number changes as predictive marker for lymph node metastasis and survival status in this group of patients. Stable chromosomal aberrations may also be used as minimal residual disease markers to followup on response to therapy. The chromosomal breakpoints defined in the current study may also contain critical genes, which are involved in the multistage carcinogenesis of GC and, thus, can serve as landmarks for crucial regions that warrant understanding the molecular basics of this cancer.

Acknowledgements: This work was supported by the Hematology, Oncology and Stem Cell Transplantation Research Center, Tehran University of Medical Sciences, Tehran, Iran under grant number 30076 


\section{References}

[1] JEMAL A, BRAY F, CENTER MM, FERLAY J, WARD E et al. Global cancer statistics. CA Cancer J Clin 2011; 61: 69-90. https://doi.org/10.3322/caac.20107

[2] LOCHHEAD P, EL-OMAR EM. Gastric cancer. Br Med Bull 2008; 85: 87-100. https://doi.org/10.1093/bmb/ldn007

[3] MCLEAN MH, EL-OMAR EM. Genetics of gastric cancer. Nat Rev Gastroenterol Hepatol 2014; 11: 664-674. https:// doi.org/10.1038/nrgastro.2014.143

[4] MITELMAN F, JOHANSSON B, MANDAHL N, MERTENS F. Clinical significance of cytogenetic findings in solid tumors. Cancer Genet Cytogenet 1997; 95: 1-8. https:// doi.org/10.1016/s0165-4608(96)00252-x

[5] KNUUTILA S, BJORKQVIST AM, AUTIO K, TARKKANEN M, WOLF $M$ et al. DNA copy number amplifications in human neoplasms: review of comparative genomic hybridization studies. Am J Pathol 1998; 152: 1107-1123.

[6] WU MS, CHANG MC, HUANG SP, TSENG CC, SHEU JC et al. Correlation of histologic subtypes and replication error phenotype with comparative genomic hybridization in gastric cancer. Genes Chromosomes Cancer 2001; 30: 80-86. https://doi.org/10.1002/1098-2264(2000)9999:9999<::aidgcc1062>3.0.co;2-r

[7] TOMIOKA N, MORITA K, KOBAYASHI N, TADA M, $\mathrm{ITOH} \mathrm{T}$ et al. Array comparative genomic hybridization analysis revealed four genomic prognostic biomarkers for primary gastric cancers. Cancer Genet Cytogenet 2010; 201: 6-14. https://doi.org/10.1016/j.cancergencyto.2010.04.017

[8] WU CW, CHEN GD, FANN CS, LEE AF, CHI CW et al. Clinical implications of chromosomal abnormalities in gastric adenocarcinomas. Genes Chromosomes Cancer 2002; 35: 219-231. https://doi.org/10.1002/gcc.10106

[9] VAN GRIEKEN NC, WEISS MM, MEIJER GA, HERMSEN MA, SCHOLTE GH et al. Helicobacter pylori-related and-non-related gastric cancers do not differ with respect to chromosomal aberrations. J Pathol 2000; 192: 301-306. https://doi.org/10.1002/1096-9896(2000)9999:9999<::AIDPATH697>3.0.CO;2-F

[10] HUDLER P. Genetic aspects of gastric cancer instability. ScientificWorldJournal 2012; 2012: 761909. https://doi. org/10.1100/2012/761909

[11] MISAWA S, HORIIKE S, TANIWAKI M, TSUDA S, OKUDA $\mathrm{T}$ et al. Chromosome abnormalities of gastric cancer detected in cancerous effusions. Jpn J Cancer Res 1990; 81: 148-152. https://doi.org/10.1111/j.1349-7006.1990. tb02541.x

[12] PANANI AD, FERTI A, MALLIAROS S, RAPTIS S. Gastric cancer with an $\mathrm{i}(8 \mathrm{q})$ and long survival. Cancer Genet Cytogenet 1992; 58: 214-215. https://doi.org/10.1016/01654608(92)90120-w

[13] PANANI AD. Cytogenetic and molecular aspects of gastric cancer: clinical implications. Cancer Lett 2008; 266: 99-115. https://doi.org/10.1016/j.canlet.2008.02.053

[14] SOBIN LH. TNM classification: clarification of number of regional lymph nodes for pN0. Br J Cancer 2001; 85: 780. https://doi.org/10.1054/bjoc.2001.1996
[15] JASS JR, SOBIN LH, WATANABE H. The World Health Organization's histologic classification of gastrointestinal tumors: a commentary on the second edition. Cancer 1990; 66: 2162-2167. https://doi.org/10.1002/10970142(19901115)66:10<2162::aid-cncr2820661020>3.0.co;2-n

[16] SHAFFER LG, MCGOWAN-JORDAN J, SCHMID M. (Eds.). ISCN 2013: an international system for human cytogenetic nomenclature (2013). Karger Medical and Scientific Publishers, Basel 2013, p 140. ISBN 978-3-318-02253-7

[17] ESPINOZA LA, BARBIERI NETO J, CASARTELLI C. Pathological and karyotypic abnormalities in advanced gastric carcinomas. Cancer Genet Cytogenet 1999; 109: 45-50. https://doi.org/10.1016/s0165-4608(98)00149-6

[18] PANANI AD, ROUSSOS C. Non-random structural chromosomal changes in primary gastric cancer. Cancer Lett 2005; 225: 291-295. https://doi.org/10.1016/j.canlet.2004.12.003

[19] KOBAYASHI M, KAWASHIMA A, MAI M, OOI A. Analysis of chromosome 17p13 (p53 locus) alterations in gastric carcinoma cells by dual-color fluorescence in situ hybridization. Am J Pathol 1996; 149: 1575-1584.

[20] BUSUTTIL RA, ZAPPAROLI GV, HAUPT S, FENNELL C, WONG SQ et al. Role of p53 in the progression of gastric cancer. Oncotarget 2014; 5: 12016-12026. https://doi. org/10.18632/oncotarget.2434

[21] YOUNG LC, KEULING AM, LAI R, NATION PN, TRON VA et al. The associated contributions of p53 and the DNA mismatch repair protein Msh6 to spontaneous tumorigenesis. Carcinogenesis 2007; 28: 2131-2138. https://doi. org/10.1093/carcin/bgm 153

[22] PENG DF, SUGIHARA H, MUKAISHO K, TSUBOSA Y, HATTORI T. Alterations of chromosomal copy number during progression of diffuse-type gastric carcinomas: metaphase-and array-based comparative genomic hybridization analyses of multiple samples from individual tumours. J Pathol 2003; 201: 439-450. https://doi.org/10.1002/ path.1459

[23] GÜMÜS-AKAY G, UNAL AE, ELHAN AH, BAYAR S, KARADAYT K et al. DNA Copy Number Changes in Gastric Adenocarcinomas: High Resolution-Comparative Genomic Hybridization Study in Turkey. Arch Med Res 2009; 40: 551-560. https://doi.org/10.1016/j.arcmed.2009.07.004

[24] YAMASHITA Y, NISHIDA K, OKUDA T, NOMURA K, MATSUMOTO Y et al. Recurrent chromosomal rearrangements at bands 8q24 and 11q13 in gastric cancer as detected by multicolor spectral karyotyping. World J Gastroenterol 2005; 11: 5129-5135. https://doi.org/10.3748/wjg.v11. i33.5129

[25] GRARDEL N, ROUMIER C, SOENEN V, LAI JL, PLANTIER I et al. Acute myeloblastic leukemia (AML) with inv (16)(p13; q22) and the rare I type CBF $\beta-M Y H 11$ transcript: report of two new cases. Leukemia 2002; 16: 150-151.

[26] LI QL, ITO K, SAKAKURA C, FUKAMACHI H, INOUE $\mathrm{KI}$ et al. Causal relationship between the loss of RUNX3 expression and gastric cancer. Cell 2002; 109: 113-124. https:// doi.org/10.1016/s0092-8674(02)00690-6 
[27] SAKAKURA C, HAGIWARA A, MIYAGAWA K, NAKASHIMA S, YOSHIKAWA T et al. Frequent downregulation of the runt domain transcription factors RUNX1, RUNX3 and their cofactor CBFB in gastric cancer. Int J Cancer 2005; 113: 221-228. https://doi.org/10.1002/ijc.20551

[28] YUSTEIN AS, HARPER JC, PETRONI GR, CUMMINGS OW, MOSKALUK CA et al. Allelotype of gastric adenocarcinoma. Cancer Res 1999; 59: 1437-1441.

[29] TAO K, WU C, WU K, LI W, HAN G et al. Quantitative analysis of promoter methylation of the EDNRB gene in gastric cancer. Med Oncol 2012; 29: 107-112. https://doi. org/10.1007/s12032-010-9805-8

[30] KIMURA Y, NOGUCHI T, KAWAHARA K, KASHIMA $\mathrm{K}$, DAA $\mathrm{T}$ et al. Genetic alterations in 102 primary gastric cancers by comparative genomic hybridization: gain of $20 q$ and loss of $18 \mathrm{q}$ are associated with tumor progression. Mod Pathol 2004; 17: 1328.-1337. https://doi.org/10.1038/modpathol.3800180

[31] KITAYAMA Y, IGARASHI H, WATANABE F, MARUYAMA Y, KANAMORI M et al. Nonrandom chromosomal numerical abnormality predicting prognosis of gastric cancer: a retrospective study of 51 cases using pathology archives. Lab Invest 2003; 83: 1311-1320. https://doi.org/10.1097/01. lab.0000087622.80751.c5
[32] HA MJ, PARK SJ, KANG HW, KIM HC, KIM HJ. [Chromosomal alterations in gastric cancer cell lines detected by comparative genomic hybridization.] J Korean Cancer Assoc 1999; 31: 219-229.

[33] ASSUMPCAO PP, ISHAK G, CHEN ES, TAKENO SS, LEAL MF et al. Numerical aberrations of chromosome 8 detected by conventional cytogenetics and fluorescence in situ hybridization in individuals from northern Brazil with gastric adenocarcinoma. Cancer Genet Cytogenet 2006; 169: 45-49. https://doi.org/10.1016/j.cancergencyto.2006.03.019

[34] PANANI AD, FERTI AD, AVGERINOS A, RAPTIS SA. Numerical aberrations of chromosome 8 in gastric cancer detected by fluorescence in situ hybridization. Anticancer Res 2004; 24: 155-159.

[35] ONCHI H, HIROSE K, YAMAGUCHI A, NORIKI S, FUKUDA M. Prognostic value of numerical aberrations of chromosome 17 in differentiated gastric cancer: evaluation by multivariate regression analysis. Oncol Rep 2000; 7: 1317-1322. https://doi.org/10.3892/or.7.6.1317 